\title{
Viral hazards of transfusion: new developments
}

The recent legal case brought in France by HIVinfected haemophiliacs ${ }^{1}$ and its dramatic outcome resulting in the imprisonment of distinguished and dedicated transfusion practitioners is one of the more deplorable of the new developments in transfusion microbiology. However, it serves to underline growing public awareness of the relevance of infectious hazards of blood transfusion; not that this relevance needs emphasising to transfusion microbiologists who themselves are aware that the value of preventive medicine is only recognised through its (usually rare) failures. Developments to improve the quality of transfusion microbiological practice and reduce the already minute risk of transfusion-transmitted infection in the UK have been progressing rapidly on many fronts as virological knowledge and technological expertise have expanded.

The introduction of routine anti-HCV screening of UK blood donors in September 1991 revealed a prevalence of HCV carriers of $c .1$ in $2000,{ }^{2}$ many of whom had acquired their infection through "dabbling" with intravenous drugs several years ago. ${ }^{3}$ Despite the more intensive current donor selection procedures, these donors continued donating because they could not believe that their brief (and often long past) exposure could have put them at any real risk. It was only when anti-HCV screening commenced that the reality of this risk was exposed. Subsequent to the anti-HCV screening, the already small risk of posttransfusion non-A, non-B hepatitis (PT-NANBH) ${ }^{4}$ is expected to reduce even further. This is most immediately demonstrated by the elimination of $\mathrm{HCV}$ infection in multi-transfused leukaemic patients undergoing intensive chemotherapy and concomitant transfusion support. Before anti-HCV screening of blood, patients' treatment was sometimes severely compromised if they became infected with $\mathrm{HCV} .{ }^{5}$ However, it should be noted that this is in contrast to the very low level of excess mortality associated with PTNANBH in transfusion recipients who had developed PTH 20 years earlier, compared with control recipients who had not developed PTH. ${ }^{6}$

Anti-HCV assays have continued to develop rapidly. Chiron corporation have considerably enhanced the formulation of their original ELISA based on the non-structural (NS) antigen c100 from the NS4 region of the HCV genome, no doubt stimulated, at least in part, by patent-challenging independent clonings of $\mathrm{HCV}^{7}$ and the use of synthetic antigens in kits such as those produced by United Biomedicals Incorporated. The range of available cloned or synthetic $\mathrm{HCV}$ antigens is now extensive and "third generation" anti-
HCV assays with antigens from the core, NS3, NS4 and NS5 genome regions are in routine use. Although at least six different $\mathrm{HCV}$ strains have been described, ${ }^{8}$ most appear to be detectable by using only the core (c22) and NS3 (c33) antigens on the solid phase. In future, specificity of assays may be improved by identifying the immunodominant regions of individual antigens and eliminating regions that are associated with false-positive cross-reactivity. In step with improvements in screening assays, the supplementary tests (which go some way towards confirming screening reactivity) have also shown dramatic improvements. Recombinant immunoblot and Western blot assays which offer an analytical approach to the determination of the range and level of antibodies to different $\mathrm{HCV}$ proteins are available from several manufacturers. The polymerase chain reaction (PCR), especially in the nested format ${ }^{9}$ whereby the first round of amplification provides products for a second round of amplification with primer pairs sited within the DNA sequence defined by the original primers, remains the most popular tool for genomic detection but for various reasons is not applicable to routine donor screening. ${ }^{10}$ Even when results are reproducible (and this is often not the case ${ }^{11}$ ) the test does not confirm antibody reactivity; furthermore, low levels of viraemia, perfectly able to infect recipients in the large volume of "inoculum" represented by a blood transfusion, may be undetected.

The issue of PCR sensitivity in relation to transfusion safety is also illustrated by the question of anti$\mathrm{HBc}$ screening to reduce the small number of residual post-transfusion $\mathrm{HBV}$ (PTHB) cases following $\mathrm{HBsAg}$ screening. Currently this is a much debated topic in the UK transfusion service where its real cost-effectiveness cannot be estimated because of the lack of central collation of the actual number of PTHB cases that still occur. In this setting, anti-HBc screening is likely to detect those few donors with anti-HBc as their sole marker of $\mathrm{HBV}$ infection (where $\mathrm{HBsAg}$ is subliminal) more effectively than PCR. Incidentally, anti-HBc screening would also detect infections caused by at least two well characterised types of HBV mutants, ${ }^{12}$ the "vaccine-escape" (HBsAg-deficient) mutants and the "e-antigen" (pre-core deficient) mutants; the latter have been reported to have caused fulminant PTHB in Japan, despite sensitive HBsAg screening of blood donations. ${ }^{13}$

Further debate surrounds the issue of whether or not to screen for anti-HTLV in the UK. Although a North London study revealed HTLV infection in 1 in 20000 (previously untested) donors, ${ }^{14}$ the very low rate 
of progression to disease in seropositive individuals makes routine screening cost-ineffective. But other strategies, such as providing screened blood for "young" or immunosuppressed patients, continue to be debated. Similarly, it has been suggested that anti$\mathrm{HBc}$ screening of "new" donors (as practised in Sweden) might provide a suitable alternative to routine anti-HBc screening. If adopted, the question of allowing anti-HBs positive (immune) donors to continue donating arises, and therefore studies to assess anti$\mathrm{HBc}$ reactivity as a "life-style" marker are currently underway. If suitably sensitive and specific combined assays for detecting several viral markers in one test become available, the pitfalls of introducing new marker screening (when not proved necessary) in a combined package will have to be borne in mind.

However these issues resolve, the need to maintain, and where appropriate improve, the quality of the screening programmes persists. Combined assay ${ }^{15}$ may reduce the often conflicting demands made of automation and computerised information transfer techniques that are now generally routine in the UK BTS although completely "walk-away" automation is still some way off. Several new developments assist us in our search for improved quality: a "go-no-go" and a probing standard for $\mathrm{HBsAg}(0.5$ and $0.125 \mathrm{IU} / \mathrm{ml}$ respectively) are now routinely available from the National Institute for Biological Standards and Control $;{ }^{16}$ coloured diluents are becoming available which change colour when sample is added; and clear guidelines are now in place nationally. Furthermore, all these improvements in the safety of the blood supply need not be made at the cost of increased wastage of false positive blood donations, as detailed protocols for the safe re-admission of donors showing false positive reactivity have recently been approved. Although the unexpected will still occur (though perhaps more rarely), such as the apparent transmission of HAV infection by certain pooled-plasma products treated by solvent-detergent to inactivate viruses, ${ }^{17}$ blood transfusion is safer than ever and causes far fewer problems than activities we take for granted, such as travelling on our roads!

J. A. J. BARBARA

Department of Microbiology, North London Blood Transfusion Centre, Colindale Avenue, London NW9 5BG.

\section{References}

1. Carrell RW, Peters K, Cash J et al. Imprisonment of J-P Allain. Lancet 1993; 342: 244.

2. Barbara JAJ. Transfusion-transmitted infections and their impact on virology. RSM Curr Med Lit, Virology 1993; 2: $67-73$.

3. Maclennan S, Barbara JAJ, Hewitt P, Moore C, Contreras M. Screening blood donations for HCV. Lancet 1992; 339: 131-132.

4. Contreras M, Barbara JAJ, Anderson CC et al. Low incidence of non-A, non-B post-transfusion hepatitis in London confirmed by hepatitis $C$ virus serology. Lancet $1991 ; 337$ : 753-757.

5. Brink NS, Chopra R, Perrons CJ et al. Acute hepatitis C infection in patients undergoing therapy for haematological malignancies: a clinical and virological study. $B r J$ Haem 1993; 83: 498-503.

6. Seeff LB, Buskell-Bales Z, Wright EC et al. Long-term mortality after transfusion-associated non-A, non-B hepatitis. $N$ Engl J Med 1992; 327: 1906-1911.

7. Glazebrook JA, Rodgers BC, Corbishley T et al. Diagnostic reagents for hepatitis C virus. Arch Virol 1992; Suppl 4 : 219-221.

8. Simmonds P, Holmes EC, Cha TA et al. Classification of hepatitis $\mathrm{C}$ virus into six major genotypes and a series of subtypes by phylogenetic analysis of the NS- 5 region. $J$ Gen Virol 1993; 74: 2391-2399.
9. Garson JA, Tedder RS, Briggs M et al. Detection of hepatitis C viral sequences in blood donations by "nested" polymerase chain reaction and prediction of infectivity. Lancet 1990; 335: $1419-1422$.

10. Barbara JAJ, Garson JA. Polymerase chain reaction and transfusion microbiology. Vox Sang 1993; 64: 73-81.

11. Zaaijer HL, Cuypers HTM, Reesink HW, Winkel IN, Gerken G, Lelie PN. Reliability of polymerase chain reaction for detection of hepatitis C virus. Lancet 1993; 341: 722-724.

12. Harrison TJ, Zuckerman AJ. Variants of hepatitis B virus. Vox Sang 1992; 63: 161-167.

13. Kojima M, Shimizu M, Tsuchimochi T et al. Post transfusion fulminant hepatitis B associated with precore-defective HBV mutants. Vox Sang 1991; 60: 34-39.

14. Brennan M, Runganga J, Barbara JAJ et al. Prevalence of antibodies to human $\mathrm{T}$ cell leukaemia/lymphoma virus in blood donors in north London. BMJ 1993; 307: $1235-1239$.

15. Barbara J. Combined testing for viral markers. In: Brown $F$ (ed) Virological safety aspects of plasma derivatives. Dev Biol Stand 81 : 81-83.

16. Ferguson M, Pipkin PA, Heath AB, Minor PD. Working standards for hepatitis $B$ surface antigen for use in the UK Blood Transfusion Service: results of a collaborative study. Vox Sang 1993; 65: 303-308.

17. Gerritzen A, Schneweis KE, Brackman H-H et al. Acute hepatitis A in haemophiliacs. Lancet 1992; 340: 1231-1232. 